\title{
Friedman and Taylor on Monetary Policy Rules: A Comparison
}

Edward Nelson

\begin{abstract}
The names Milton Friedman and John Taylor are associated with different monetary policy rules; but, as shown in this paper, the difference between their perceptions of how the economy works is not great. The monetary policy rules advanced by Taylor and Friedman are compared by linking the rules to the two economists' underlying views about nominal rigidity, the source of trade-offs, the sources of shocks, and model uncertainty. Taylor and Friedman both emphasized Phillips curve specifications that impose temporary nominal price rigidity and the long-run natural-rate restriction; and they basically agreed on the specification of shocks, policymaker objectives, and trade-offs. Where they differed was on the extent to which structural models should enter the monetary policy decisionmaking process. This difference helps account for the differences in their preferred monetary policy rules. (JEL E42, E51, E61)
\end{abstract}

Federal Reserve Bank of St. Louis Review, March/April 2008, 90(2), pp. 95-116.

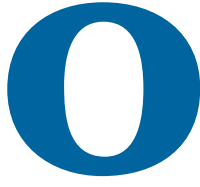

ver 25 years ago, John Taylor observed, "Of course, you have to go back and try to interpret what early economists actually said. Because they were never quite as explicit as economists tend to be now, this is not easy." 1 Taylor probably did not have Milton Friedman in mind when he made those remarks. But, in retrospect, they fit Friedman very well, as Friedman's work rarely used models that were very explicit, especially by today's standards. Moreover, Friedman qualifies as a significant "early economist" for the research areas that Taylor has been most associated with: nominal rigidities, the role of expectations in price setting, welfare analysis and trade-offs for monetary policy, and monetary policy rules. In the discussion that follows, I attempt to provide a systematic comparison of Friedman's and Taylor's views

1 November 1982 remarks, quoted in Klamer (1983, p. 173). on these issues and their implied modeling choices.

\section{OBJECTIVE FUNCTION}

How do Friedman's and Taylor's views of policymaker objective functions compare? Taylor was more explicit on this issue, so I consider him first.

\section{Taylor on Policymaker Objectives}

As is well known, Taylor (1979) worked with a policymaker objective function that penalized deviations of inflation from a target and output from its natural level. The function consisted of the expected value of the sum across periods of the loss function,

$$
\lambda\left(y_{t}-y_{t}^{*}\right)^{2}+(1-\lambda)\left(\pi_{t}-\pi^{*}\right)^{2}, \lambda \in[0,1],
$$

Edward Nelson is an assistant vice president and economist at the Federal Reserve Bank of St. Louis. An earlier version of this paper was presented at the session, "Looking Back: Historical Perspective on Taylor Rules," for the Federal Reserve Bank of Dallas conference, "John Taylor's Contributions to Monetary Theory and Policy,” October 12-13, 2007. The author thanks Otmar Issing, Benjamin Keen, Kevin Kliesen, Evan Koenig, and John Taylor for helpful comments on an earlier version of this paper. Faith Weller provided research assistance.

(C) 2008, The Federal Reserve Bank of St. Louis. Articles may be reprinted, reproduced, published, distributed, displayed, and transmitted in their entirety if copyright notice, author name(s), and full citation are included. Abstracts, synopses, and other derivative works may be made only with prior written permission of the Federal Reserve Bank of St. Louis. 
where $y_{t}-y_{t}^{*}$ is the output gap (i.e., the difference between the logs of output and the value that output would take if there were no nominal rigidities), $\pi_{t}$ is inflation, and $\pi^{*}$ is an inflation target. Taylor subsequently argued that this choice of objective function was an implication of rational expectations models that included nominal rigidities:

[T] he objective of macroeconomic policy is to reduce the size (or the duration) of the fluctuations of output, employment, and inflation from normal or desired levels...[T] he rational expectations approach is fairly specific about what the objectives of policy should be. Changing the natural or normal levels of output and employment is not the direct objective of stabilization policy...As a first approximation, these normal levels are not influenced by macroeconomic policy...[I]t is important to choose a target [inflation] rate that maximizes economic welfare...[and] to minimize fluctuations around the target... (Taylor, 1986a, pp. 159, 160)

On the other hand, Taylor (1986a, p. 153) conceded that rational expectations models with staggered nominal contracts "need some bolstering of their microeconomic foundations"; he also described the aforementioned stabilization goal as the "assumed goal" (1987, p. 351), not necessarily the model-implied goal. In fact, staggeredcontracts models with deeper microfoundations and a model-consistent welfare function do largely support the loss function that Taylor used, as shown by Rotemberg and Woodford (1997). ${ }^{2}$ There are, however, two major qualifications:

First, the setting of the output target at the natural output level is not automatically implied by these models. One case that delivers a zerooutput-gap target is when the natural level of output corresponds to the efficient level of output. This is essentially what occurs in Rotemberg and Woodford (1997): Though their model contains imperfect goods-market competition and so tends to deliver inefficiently low aggregate output, they

\footnotetext{
2 The Rotemberg-Woodford objective function that sums the loss function across periods does differ from the one that Taylor proposed, because Taylor argues for no discounting (see Taylor, 1979, p. 1276, and 1986a, p. 159; and Hall and Taylor, 1997, p. 474); whereas, Rotemberg and Woodford recommend that the welfare function feature discounting (using the representative household's rate of discount).
}

assume that a fiscal subsidy raises steady-state output to the efficient level.

Alternatively, the natural level of output may be lower than the social optimum, but the monetary authority might explicitly disown attempts to push output above its natural value. Taylor has consistently advocated this stance, most explicitly in Taylor (1987); it is also the position taken by McCallum (1995), King (1997), and Svensson (1997). ${ }^{3}$ Specifically, Taylor has argued that monetary policy analysis should not concern itself with whether the natural level of output is efficient and should instead treat the natural level as the value around which output should be stabilized (Taylor, 1987, p. 351; Hall and Taylor, 1997, p. 478).

The zero-output-gap target is natural to Taylor because it captures the message of the natural rate hypothesis. He has always endorsed this hypothesis in his writings, maintaining (i) that models should reflect and that policymakers should take into account the notion that "the economy tends to return to the natural rate of unemployment" irrespective of monetary policy rule and (ii) that, conformably, "no long-term relationship exists between inflation and the deviation of real GDP from potential GDP."4 With no scope for policymakers to steer output away from the natural level in the long run, a loss function featuring a zerooutput-gap objective better reflects the economic structure. Likewise, Taylor has not been in favor of economic analysis that postulates a policymaker desire to target a positive output gap, either in positive economics or normative applications. This was a major reason why Taylor was one of the earliest to speak out against time-consistency explanations for the Great Inflation, which rely on policymakers having an output target in excess of the natural level of output (see, e.g., Taylor, 1992, pp. 14-15).

\footnotetext{
3 As shown in Woodford (2003), a model with inefficient potential output and no subsidy usually does not admit a quadratic approximation for the welfare function. My conjecture is that in this environment the Taylor (1987) procedure amounts to the following: As far as is possible, rewrite the approximation of the welfare function so that terms in output appear as deviations from potential output; any left-over output terms are then ignored when the policymaker carries out optimization.

4 The quotations regarding unemployment and gross domestic product (GDP) are from Taylor (1987, p. 351) and Taylor (1994, p. 38).
} 
The second qualification is that the presence of wage stickiness means that price-inflation variability is generally not the only inflation term in the social welfare function; wage-inflation variability appears too (Erceg, Henderson, and Levin, 2000). I defer discussion of wage stickiness in Taylor's framework until later in the paper.

\section{Friedman on Policymaker Objectives}

A close reading of Friedman's work suggests that he favored a policymaker objective function close to that advanced by Taylor-that is, one penalizing inflation deviations from target and output gap deviations from zero, with no other terms in the objective function. Moreover, he believed that by the early 1980s policymakers had moved to a strategy meant to pursue this objective.

To establish this interpretation of Friedman's position, the first thing to note is that his advocacy of monetary targeting (discussed further below) did not amount to a denial of the position that the principal objective of monetary policy should be price stability. Though believing that real money holdings generate utility (see Friedman, 1969), Friedman did not base his advocacy of monetary targeting on this component of utility; he did not list stability in real money balances as an ultimate objective. ${ }^{5}$ Rather, the appropriate welfare function for monetary policy puts highest weight on price stability:

With respect to ultimate objectives, it's easy to cite the holy trinity that has become standard: full employment, economic growth, and stable prices...What is the special role of monetary policy in contributing to these objectives?... [T] here is today a worldwide consensus, not only among most academic economists but also among monetary practitioners, that the long-run objective of monetary policy must be price stability. (Friedman, 1982a, p. 100)

As would be expected from his work on the natural rate hypothesis (Friedman, 1968),

5 Friedman specifically disavowed the rule he derived in his 1969 paper as one that monetary policymakers should or did use to conduct policy; so, he was not interested in bringing the level of real balances to the value that satiated households.
Friedman interpreted the full-employment objective as a stabilization objective-that is, minimizing fluctuations in the output gap. Therefore, the goals of policy should be "a reasonably stable economy in the short run and a reasonably stable price level in the long run" (Friedman, 1959, p. 136).

Friedman acknowledged that the stabilization objective could in principle be pursued jointly with the price-stability objective, in which case one would be "pursuing the long-run policy in a manner that contributes to minimizing economic fluctuation" (Friedman, 1982a, p. 100). He also indicated that he did not disagree with the weights in the objective function used in Keynesian work. ${ }^{6}$ Acceptance of such an objective function would imply some allowance, in setting policy, for tradeoffs between objectives to the extent that such trade-offs existed. Friedman granted this in principle, subscribing to the view that in public policy there should be "a sane balance among competing objectives” (Friedman, 1979a). Indeed, Friedman's belief in the existence of a short-run output gap/ inflation trade-off, considered further below, was one reason for his preference, in a situation starting from high inflation, for a progressive stepdown in money growth toward a constant money growth rule. He argued that such a program offered a way of managing the short-run trade-off that was superior to what had been pursued in practice during the Volcker disinflation. The Volcker disinflation, he argued, had brought inflation down too quickly and produced a deeper-than-necessary trough in output. ${ }^{7}$ Further details of the arguments underlying Friedman's advocacy of constant money growth can be brought out by considering his and Taylor's positions on monetary policy rules.

\section{MONETARY POLICY RULES}

It is tempting to think of Friedman and Taylor as being on opposite ends of the spectrum on the

6 "I doubt very much that there is any significant difference between [Modigliani] and me, for example, on the value judgments we attach to unemployment and inflation" (Friedman, 1977a, p. 12).

7 Friedman and Friedman (1984, pp. 91-92). 
issue of monetary policy rules. That may seem a natural conclusion given the rules they came to advocate: Friedman, a constant money growth rule; Taylor, an activist interest rate rule. And, yes, Taylor (1982) went on record with the view that Friedman's constant money growth rule was "extremely undesirable." But focusing on this statement by Taylor, or on a contrast between Taylor's (1993a) rule and Friedman's monetary rule, would lead one to overstate the differences between the two on the issue of policy rules. As we will see, Taylor has often emphasized the links between his recommendations and those of Friedman; in particular, the focus on a nonaccommodative and rule-based policy. Taylor also downplayed the distinction between money growth and interest rate rules. Where Friedman and Taylor differ most is in their judgments about the extent to which monetary policy should be based on assumptions about the structural behavior of the economy. This starting point leads naturally to different judgments about the appropriate degree of activist stabilization policy and also about the connection of policy decisions to ultimate policy objectives.

\section{Friedman's Framework}

Friedman's money growth rule separates the variables that he believed should appear in the policymaker objective function (inflation and the output gap) from the variable that policy should directly target (money or money growth). The focus on an intermediate variable and on a nonactivist rule reflected his opposition, discussed below, to deploying optimal control methods; more generally, it reflected his doubts about the practical success of monetary policy rules that responded to ultimate objectives or rested on structural economic models.

Friedman's opposition to responding to ultimate objectives was based on somewhat distinct rationalizations for the two ultimate objectives, inflation and the output gap.

Inflation. Friedman noted that monetary policy affected inflation with a lag; current inflation was therefore unsuitable as a target, and inappropriate as a variable on which to feed back, because that "would produce a monetary policy that was always fighting the last war."8 Targeting expected future inflation, on the other hand, would require too much reliance by policymakers on their estimates of structural relationships linking monetary policy actions and inflation (i.e., inflation behavior would be sensitive to the specification of the IS, LM, and Phillips curve relationships); and policy actions could then be destabilizing in practice: hence, Friedman's judgment that responding to prices or inflation implied "a bad rule although a good objective" and his conclusion that a "rule in terms of the quantity of money seems...far superior, for both the short and the long run, than a rule in terms of price-level stabilization."9

Nevertheless, Friedman did not regard activist rules that responded to inflation, nominal income, or nominal income growth as nonmonetarist. He noted that an implication of his own research was that "monetary policy is an appropriate and proper tool directed at achieving price stability or a desired rate of price change" (Friedman, 1977a, p. 13). Though targeting nominal variables other than the money stock required too much fine-tuning for Friedman's liking, he saw them as monetarist rules because they shared "the quantity theory emphasis on nominal magnitudes" (Friedman, 1987, p. 18). This way of phrasing matters actually does not adequately reflect the relationship between the quantity theory and policy rules. A more precise way of putting things is that these rules reflect the quantity theory's emphasis on nominal magnitudes as the variables ultimately determined by the monetary authorities. Many expositions of the quantity theory, including some of Friedman's, do emphasize real variables, but as variables determined in the long run by factors other than monetary policy.

\footnotetext{
8 Friedman (1982b). This argument foreshadowed Bernanke et al.'s (1999, p. 298) criticism of "policies that react to inflation only after it has become a problem," although their suggested solution, in contrast to Friedman's proposals, was to concentrate on expected future inflation. As it turns out, policy rules that respond to current inflation typically perform well-i.e., are stabilizing-in simulated New Keynesian models, largely because the forward-looking nature of price setting compensates for the delayed character of the policy response.

9 The quotations are from Friedman (1982b) and Friedman (1967, p. 4; p. 84 of 1969 reprint).
} 
Output Gap. Friedman's most important basis for excluding real variables from the list of targets was the natural rate hypothesis: Real variables reverted to their natural values in the long run, irrespective of what monetary policy did. This position, however, was not a satisfactory basis for denying monetary policy a stabilization role. In principle, as Friedman (1968) acknowledged, the absence of a long-run influence still left real variables as candidate data on which policy might feed back, provided they appeared in gap form. Gaps would likely provide information about inflation; moreover, the stabilization of gaps was itself a desirable goal.

But Friedman came out against policy responses to unemployment or output even when these were expressed as deviations from natural values; instead, he argued, full employment should not be sought "directly" by monetary policy (Friedman, 1982a, p. 100). First, the lack of knowledge required for fine-tuning again produced the danger of policy being destabilizing in practice. Second, targeting a gap variable required estimation of the unobserved natural rates of interest, output, or unemployment: In principle, this was subject to bias because "it is almost impossible to define full employment in a way that is logically precise"; in practice, it had resulted in "unduly ambitious targets of full employment."10 Stabilization policy intended to promote a zero output gap had thus led to unintended targeting of positive gaps, making inflation worse. Money growth targeting protected monetary policy from problems associated with responding to gaps.

There are clear links between these positions and the work of Orphanides (2003) on the danger of relying on real-time measures of the output gap when formulating policy. Orphanides himself motivates his work with statements from Friedman going back to the 1940s. Orphanides also notes that Friedman's money rule is in terms of growth rates; it is based on data that tend not to have the large serially correlated revisions associated with levels of series. Friedman's money growth rule

\footnotetext{
${ }^{10}$ The quotations are from Friedman (1963; p. 40 of 1968 reprint) and Friedman and Friedman (1980, p. 311).
}

was also insensitive to data revisions for a more subtle reason: Although Friedman generally advocated an M2-type aggregate as the monetary target, he stressed that an important advantage of the rule used to hit the M2 target is that the implied open market operation could be announced ahead of time (see especially Friedman, 1982a). That is, Friedman's M2 growth rule is less usefully thought of as a targeting rule (as in Svensson, 2005) than as an operational instrument rule (as in McCallum and Nelson, 2005). Accordingly, information obtained in subsequent periods would not lead to a different retrospective prescription from the rule, even if such information would have secured more precision in hitting the M2 target. Data revisions would fall into this category. Strictly speaking, therefore, Friedman's money growth rule prescription is not subject to a real-time/final data distinction.

Friedman (1960, pp. 23, 98) freely acknowledged that a constant money growth rule did not correspond to optimal monetary policy. Rather, he offered it as a way of preventing both the policy mistakes that could result from activist monetary policy in the presence of imperfect knowledge and repetition of the historical policy mistakes that had been associated with large variations in the money stock. The latter consideration comes out in Friedman's statement that "the major argument for the rule has always seemed to me to be far less that it would moderate minor cyclical fluctuations than that it would render impossible the major mistakes in monetary policy that have from time to time had such devastating effects."11

\section{Monetary Policy Rules in Taylor's Framework}

Taylor saw rational expectations as changing the monetary policy debate from being about "rules versus discretion" to being about the choice of monetary policy rule:

$[\mathrm{M}]$ acroeconomic policy should be stipulated and evaluated as a rule, rather than as one-time changes in the policy instruments...There is a big distinction between "discretionary" and

\footnotetext{
${ }^{11}$ Friedman (1966a; 1969 reprint, p. 154).
} 
"activist" policies...Activist and constantgrowth-rate policy rules have much more in common with each other than do activist policy rules and discretionary policy. (Taylor, 1986a, pp. 155, 157)

Taylor therefore was not inclined to see the constant money growth rule as being in a different spirit from the feedback rules, nor did he always stress a contrast between interest rate and money growth rules. He looked on arrangements that used money as the instrument as implying a particular form of the interest rate rule, and he wrote favorably of aspects of a constant money growth rule in that light: Fixed money growth implied "an automatic increase in the interest rate" when aggregate demand rises, and this was one of the rule's "stabilizing properties" (Taylor, 1999a, pp. 64-65). Confirming these stabilizing properties of a constant money growth rule, Taylor (1979, p. 1282) found in simulations that the rule produced a lower output gap variance than did the historical postwar U.S. policy rule.

But the fact is that Taylor was never a supporter of a constant money growth rule, coming up with an alternative rule in his published research in 1979 (Taylor, 1979) and strongly rejecting constant money growth as a desirable policy option in a Congressional submission in 1982 (Taylor, 1982). His own proposed activist rules have evolved from optimal-control-based rules in the 1970s, to simple policy rules for money in the early and mid-1980s, to his advocacy of interest rate rules today. The constant theme has been rule-based policymaking with feedbacks but with lack of accommodation of inflation.

\section{Optimal Control}

An initial source of disagreement between Friedman and Taylor in the 1970s was the value of optimal control in monetary policy analysis. The disagreement is made clear by simply juxtaposing the title of Taylor's (1979) paper "Estimation and Control of a Macroeconomic Model with Rational Expectations" against Friedman's (1973a, p. 9) statement that "control theory...requires delicate fine-tuning for which the Fed has neither the knowledge nor the demonstrated capacity."

This did not become, however, the area of durable disagreement between Taylor and Friedman on rules. By the early 1980s, Taylor was deemphasizing optimal control in favor of simple policy rules (see, for example, Taylor, 1981a). He stressed that optimal control was complex and model-specific (Taylor, 1986a, p. 162) and at this point what he emphasized instead was "a simpler rule," relying on few arguments, which might be a good approximation of optimal policy in Taylor's model but by implication was less model-sensitive.

\section{Taylor's Move to Simple Rules}

These early rules had the money supply as the policy instrument. Taylor (2007, p. 195) has described the money supply rule inspired by his 1979 analysis as "effectively a 'Taylor rule,' though for the money supply." Experiments in Taylor (1981a) intended to determine the best simplerule approximation to the optimal rule of 1979 actually reached a rule with somewhat different arguments from those in the Taylor rule. Instead of responding to inflation and the output gap, the simple rule for money growth had no inflation term, with responses to the output gap and the change in the output gap. But the absence of inflation from the money growth rule is not a source of material difference from the Taylor rule. A zero response of money growth to inflation implies policymaker non-acquiescence to the existing inflation rate, while anything short of a largerthan-unit response of an interest rate rule to inflation will (other things equal) tend to perpetuate the existing inflation rate, or worse. The simplified 1979 money rule therefore is qualitatively similar to the Taylor rule in that it is nonaccommodative and both rules encapsulate Taylor's (1986a, p. 162) position that "monetary policy has a stabilization role but no accommodation role." The nonzero response to the change in the output gap (a speed-limit response) is a material difference between the simplified 1979 rule and the Taylor rule. But estimates of interest rate rules inspired by the Taylor rule sometimes allow for a speed-limit response by including more than 
one lag of the output gap (or of detrended output) as regressors (see, for example, Rotemberg and Woodford, 1997).

Taylor was unequivocal on the point that his proposed feedback rules were preferable to Friedman's money growth rule: “[A] specific activist rule would work better than a monetarist rule” (Taylor, 1986a, p. 162). He recognized, as many had not, that Friedman had never claimed that a money growth rule was optimal. The claim that the money growth rule could not be beaten was a product of the flexible-price rational expectations literature, not a contention of Friedman's. Indeed, Taylor offered one of Friedman's most clear-cut statements on the issue: "A believer in monetarist theory still can favor an activist monetary policy as a way to offset other changes in the economy."12 Taylor understood that Friedman's case for a money growth rule rested instead on a model-uncertainty argument. But Taylor disagreed with Friedman on the quantitative importance of this issue and rejected model uncertainty as the basis for refraining from activist rules. Taylor's definitions of policy rules tended to presume an activist rule, as in his reference to policy rules as "the way the policymakers respond to events" (Taylor, 1986b, p. 2039).

In discussing Taylor's position on activism, I find it useful to separate the discussion into two issues: allowing the money supply to respond to money demand shocks; and then, more generally, systematic monetary policy responses to other economic shocks.

Money Demand Shocks. An area of direct disagreement between Friedman and Taylor was whether the monetary policy rule should attempt to accommodate money demand shocks. Friedman argued that there was too much uncertainty about money demand to make accommodation desirable:

In principle, if we knew about autonomous changes in the real demand for money, it would be right to adjust the nominal supply to them. However, we don't know about them. (Friedman, 1973b, p. 31)

\footnotetext{
${ }^{12}$ Friedman (1984, p. 3), quoted in Taylor (1986a, p. 153).
}

[W] hat you really have to demonstrate is that, over time, you will in fact know enough about such changes and will be able to identify them soon enough, so that you can make adjustments which, on the average, will do more good than harm. (Friedman, 1977a, p. 26)

There is considerable substance to this reservation on Friedman's part. How much accommodation is needed to insulate the economy from money demand shocks is not a question that can be put on autopilot. For example, using changes in velocity to gauge the required amount of monetary accommodation is not without problems. Because velocity is defined residually as the ratio of nominal GDP to money, a velocity movement might reflect not a permanent money demand shift, but instead a faster response of money than of nominal income to a shock that will ultimately move income by the same amount as money. Of course, holding the nominal interest rate constant in the face of a money demand shock will mean that the shock is accommodated one-for-one, but it will also mean that other shocks that create pressure on interest rates will be accommodated. Thus Friedman feared that a scheme other than constant money growth would provoke monetary responses to "all sorts of changes that...should not be accommodated" (Friedman, 1977a, p. 18).

This criticism applies more fundamentally to interest rate pegging than to an appropriately formulated, non-accommodative, interest rate rule; it would not usually apply to the Taylor rule, for example. In fact, while Friedman was a notable critic of using the short-term nominal interest rate as a policy instrument, his two main objections were not generic criticisms of interest rate rules, but instead highlighted two particularly weak types of rule: pure rate pegging and rules that did not take into account the nominal rate/real rate distinction. It is true that, in the 1960s and 1970s, examples of successful interest rate rules were hard to find, so that one was more entitled to the presumption that movement to a base money rule was in practice necessary for delivering the requisite anti-inflationary movements of interest rates. When considering the choice between instrument rules that were more competitive with one another-that is, money base instrument rules 
versus nominal interest rate rules that incorporated vigorous responses to nominal variablesFriedman continued to be in favor of base rules, but admitted that it was a tactical, not a strategic, issue.

Taylor, by contrast, has been consistently more optimistic than Friedman on the scope for monetary policy to offset money demand shocks. Taylor (1982) observed the following:

In my view, however, it is possible for the monetary authorities to discover shifts in money demand and to react to them with a relatively short lag. Such shifts should be accommodated by changing the supply of money.

Other Shocks. Taylor (1992, p. 29) observed that "good policy is characterized by systematic responses to economic shocks." Identifying economic shocks such as disturbances to the Phillips curve, production function, and preferences and determining the stabilizing policy reaction are surely even more model-dependent exercises than in the case of money demand shocks. Accordingly, Taylor firmly associated himself with using structural models, both in policy analysis and policy formulation. He judged that the appropriate response to the Lucas critique was to use models whose parameters (including parameters governing nominal rigidity) could be legitimately treated as structural and not as functions of the policy regime. ${ }^{13}$ Monetary policy rules could then be coherently analyzed with these models. Moreover, he stressed that structural models should be used in policymaking: "[P]olicy actions should be based on structural relationships" and "structural models...might be useful for formulating policy."14

The position that policymakers should use structural models is also implied by Taylor's advocacy of monetary policy rules that include a response to the output gap. Taylor (1999a, p. 63) acknowledged "a large degree of uncertainty about measuring potential GDP (and, thus, the output gap)." But he argued that the appropriate

\footnotetext{
${ }^{13}$ See Taylor (1986a, p. 156; 1986b, p. 2038).

${ }^{14}$ The quotations are from Taylor (1981b, p. 81) and Taylor (1993b, p. 5).
}

policy reaction to this uncertainty was to use a simple policy rule with a reduced, but still positive, response to the output gap (Taylor, 1999a, pp. 63-64). He has encountered this issue both in his policy and research work. While at the Council of Economic Advisers in 1976-77, Taylor was involved in a major downward revision of potential output that was published in the 1977 Economic Report of the President. Furthermore, in his early work Taylor used output gap estimates that implied an average postwar gap for the United States of -1.9 percent (Taylor, 1979, p. 1282); afterward he used more economic structure when estimating the gap, by imposing the natural-rate-hypothesis condition that the gap be zero on average in postwar data (see, for example, Taylor, 1986c, p. 641).

Taylor also acknowledged that the Taylor rule requires an estimate (for the intercept term in the rule) of the steady-state equilibrium real interest rate, but he has rejected this problem as a justification for turning to money growth rules. Instead, he has argued that the way to overcome policy errors that might result from a biased equilibrium-rate estimate is to increase the response to inflation in the interest rate rule (Taylor, 1994, p. 26).

Even in 1982 during the new-operatingprocedures period, Taylor thought of the Fed as operating on interest rates. ${ }^{15}$ So, whereas his early work used money growth rules, Taylor was probably more accustomed than most U.S. monetary economists at the time to viewing monetary policy in terms of an interest rate rule. By 1992 he had concluded that the monetary policy literature would now focus on rules "probably with the interest rate as the instrument" (Taylor, 1992, p. 15). Because even his proposals for money supply rules involved accommodation of money demand shocks (and other sources of permanent velocity movement), Taylor did not see a dramatic normative contrast between money stock rules

\footnotetext{
15 "[T]he Fed would have to contract demand by increasing interest rates" (Taylor, 1982). Also, Taylor (1981b, p. 78) thought of stabilization policy in terms of policy influence on real interest rates on securities and noted the zero lower bound on nominal interest rates as an obstacle to achieving the required real interest rate movement.
} 
and interest rate rules and he emphasized the mapping between money growth rules and interest rate rules. ${ }^{16}$ But a focus on interest rate rules made it easier to compare proposed rules with reaction functions used in historical and presentday monetary policy.

\section{Friedman's Later Views on Rules}

It would be inaccurate to say that Friedman ever stopped favoring fixed money growth as his first preference for a monetary policy rule. But his criticisms of alternative rules did diminish in the 1990s. He acknowledged that understanding of the economy had improved since the 1960s and that he had been surprised at the success with which this knowledge had been translated into successful stabilization policy by policymakers since the mid-1980s. Moreover, financial changes had unambiguously made money harder to define, reflected in the increased tendency for alternative monetary aggregates to give different signals; in that environment, money growth targeting did not imply stepping away from activism, given the increased difficulty of settling on the right concept of money and hitting the target. He still saw value in a money growth rule as a constraint on policymaker discretion. And Japan's experience in the 1990s served as Friedman's trump card in support of his older arguments, suggesting to him that a money growth rule might still be preferable to an interest rate reaction function based on ultimate objectives.

\section{SOURCES OF NOMINAL RIGIDITY}

Nominal rigidity plays a central role in both Friedman's and Taylor's views of the transmission mechanism. They each contributed theoretical breakthroughs related to nominal rigidity: the natural rate hypothesis in Friedman's case; staggered contracts in Taylor's. As I will discuss, both of them emphasized simultaneous wage and price stickiness. At the same time, I believe that their views of the transmission mechanism are actually better represented by a model in which

\footnotetext{
${ }^{16}$ See, for example, Taylor (1998, pp. 5-6; 1999b).
}

there is little wage stickiness and that their views on the social welfare function are to some extent inconsistent with the existence of substantial wage stickiness.

\section{Friedman on Nominal Rigidity}

Turning to Friedman first, I have occasionally seen interpretations of his view of the transmission mechanism that characterize him as making an implicit assumption of both price and wage flexibility - so that the effect of monetary policy on output comes only from imperfect information. ${ }^{17}$ But in fact such a vision is not implicit in his view of the economy, and the explicit record of Friedman's writings shows repeated stress on the role of nominal rigidity. Taylor (1999c) recognized this by opening his article on nominal rigidities with a capsule Friedman quotation from 1982: "Prices are sticky."18 Indeed, as early as 1967, Friedman described himself as "in full agreement" with the view that it "is the rigidity of prices that converts fluctuations in aggregate demand into fluctuations in output and employment." ${ }^{19} \mathrm{He}$ made specific reference to "wage and price contracts" in one of his earliest expositions of the vertical Phillips curve idea (Friedman, 1966b).

Taking for granted therefore that Friedman had in mind a long-run vertical expectational Phillips curve based on nominal rigidity, what is the most appropriate way of formalizing his views further? I find it useful to break the discussion of Friedman's price adjustment ideas into several considerations: whether the expectations term is formed rationally, whether prices are a "jump" or predetermined variable, and the date of the expectation in the Phillips curve (i.e., whether it refers to inflation in period $t+1$ or $t$ and whether this expectation is based on an information set from period $t$ or period $t-1$ ). I defer until my

\footnotetext{
${ }^{17}$ See the Nobel Committee (2006) for a recent discussion in which this position is attributed to Friedman.

${ }^{18}$ Friedman (1982c). In addition to opening Taylor's chapter (1999c), this quotation also appears in Hall and Taylor (1997, p. 235).

${ }^{19}$ Friedman (1967, pp. 2, 6; pp. 82, 86 of 1969 reprint). The rigidity Friedman endorsed as relevant was temporary nominal rigidity, rather than the permanent nominal rigidity which he associated with early Keynesianism.
} 
discussion of Taylor the issue of whether nominal rigidity pertains to wages or prices in Friedman's framework.

\section{Forward-Looking Behavior}

Though he is often associated with adaptive expectations and with accelerationist versions of the natural rate hypothesis, Friedman does not appear to have been opposed to rational expectations in principle. He accepted that it was "most unreasonable" to use adaptive expectations when this involves extrapolating from a different regime (Friedman and Schwartz, 1982, p. 569) and suggested that rational expectations models were acceptable, provided they got away from the implication of serially uncorrelated effects of monetary policy on output (Friedman, 1977a, p. 14). He spoke out in favor of rational expectations models with long-term nominal contracts and defended these models against critics of rational expectations (Friedman and Schwartz, 1982, p. 415).

The above elements suggest that a forwardlooking Phillips curve represents Friedman's views well. He did suggest (see Friedman, 1974a) that commodity price shocks could stimulate inflationary expectations, a suggestion that might imply the presence of some price indexation and a lagged inflation term in the Phillips curve. But there is strong evidence that he did not believe in full indexation: The aforementioned effect of commodity price shocks on expectations was described as temporary, and Friedman emphasized the need for reforms to make indexation more widespread and so reduce relative price distortions (see Friedman, 1974b). ${ }^{20}$

\section{Prices: Jump or Predetermined}

Friedman (1979b) noted the existence of

contractual arrangements that fix prices and wages in advance for some time. Even when prices and wages are not fixed explicitly, it is often undesirable to change them frequently. As a result, output and employment are gen-

\footnotetext{
${ }^{20}$ In this respect, Friedman anticipated the cost of inflation that is emphasized in the New Keynesian literature. See Nelson and Schwartz (2008) for further discussion.
}

erally more flexible over short periods than prices and wages, though less flexible over long periods.

While recognizing here the existence of longterm price contracts, Friedman nevertheless believed that a portion of the aggregate price index is a jump variable. It is clear from his expositions on the vertical Phillips curve (e.g., in Friedman, 1966b, 1968) that he saw some prices as able to increase immediately when nominal aggregate demand rises. Therefore, the price level is a jump variable notwithstanding the presence of a predetermined subset of prices. As Friedman (1974b, p. 30) put it, "Some prices... are fixed a long time in advance; others can be adjusted promptly."

The coexistence of some predetermined prices and some "jump” prices makes Friedman's framework compatible with a Calvo (1983) or Taylor price contract scheme, but not with Rotemberg (1982) price setting.

\section{Reference Date for Expectations}

Does the expected-inflation term in Friedman's Phillips curve refer to inflation in period $t$ or period $t+1$ ? And when are these expectations formed? Traditionally, the expectedinflation term in Friedman's Phillips curve is interpreted as being lagged expectations of current inflation: that is, $E_{t-1} \pi_{t}$. Certainly the $t-1$ date on expectations formation is justified: Friedman (1974b, p. 30) said, "It will take still more time before expectations about inflation are revised"; that is, expectations of $\pi$ are inertial relative to $\pi$ itself.

In some of Friedman's discussions, it is implied that the inflationary expectations that matter for period- $t$ inflation are forward-lookingthat is, they pertain to expectations of policy beyond period $t$. For example, Friedman (1966b) said that prices are "set in the light of anticipations of inflation." Friedman (1972) argued that business decisions depend on confidence in future monetary policy and that a preannounced policy of steady money growth was more stabilizing than a discretionary policy that ex post delivered the same degree of steadiness in money growth. And Friedman and Friedman (1980, p. 
326) observed that inflation expectations depend on signals about future policy. So Friedman's framework is compatible with $E_{t-1} \pi_{t+1}$ rather than $E_{t-1} \pi_{t}$ in the Phillips curve.

Summing up, Friedman's Phillips curve views seem to be in line with the Christiano, Eichenbaum, and Evans (2005) generalization of Calvo contracts, as expressed in output gap space by Giannoni and Woodford (2005):

$$
\begin{aligned}
& \left(\pi_{t}-\gamma \pi_{t-1}\right)= \\
& \left(E_{t-1} \pi_{t+1}-\gamma \pi_{t}\right)+\alpha\left(y_{t}-y_{t}^{*}\right)+u_{t}, \alpha>0 .
\end{aligned}
$$

Relative to Giannoni-Woodford, equation (2) has been modified by (i) imposing a verticalPhillips-curve restriction (i.e., a unit weight on expected inflation), following Roberts (1995); and (ii) allowing some response by a portion of firms to current information by making the output gap appear in realized rather than expected form. In both cases, the modifications are designed to make the specification better reflect Friedman's views. For reasons discussed above, the indexation coefficient $\gamma$ is likely nonzero, but low, in Friedman's framework. I will discuss the costpush shock term $u_{t}$, familiar from Clarida, Galí, and Gertler (1999) as an addition to the New Keynesian Phillips curve, when I turn to sources of trade-offs.

\section{Taylor on Nominal Rigidity}

Taylor argued in 1982 (in Klamer, 1983, p. 174), "I do not think that you can accurately model macroeconomic behavior assuming that prices are perfectly flexible.” That view has underpinned Taylor's emphasis on contracting models. It is also implied by Taylor's emphasis, since the 1970s, on the output gap concept and on stabilization of the output gap as a goal to be pursued through monetary policy rules. This approach distinguished him from many earlier users of rational expectations models. In most of these early models, the flexible-wage/flexibleprice assumption meant that the gap was identically zero or, at best, a white noise process incapable of being influenced by activist, predictable monetary policy actions.
Taylor has proposed a very specific Phillips curve, based on staggered contracts. Neglecting shock terms for the moment, we see in the twoperiod-contract case that this is built up from a "basic...contract determination equation" for the log contract,

$$
\begin{aligned}
& z_{t}=0.5 z_{t-1}+0.5 E_{t} z_{t+1}+ \\
& \xi\left[\left(y_{t}-y_{t}^{*}\right)+E_{t}\left(y_{t+1}-y_{t+1}^{*}\right)\right], \xi>0,
\end{aligned}
$$

and an "aggregate price level" definition describing log prices, $p_{t}=0.5 z_{t}+0.5 z_{t-1}$-the latter definition presuming a constant markup (Taylor, 1981b, p. 72). After some further approximations (see Roberts, 1995), ${ }^{21}$ the result is a version of the New Keynesian Phillips curve:

$$
\pi_{t}=E_{t} \pi_{t+1}+\alpha\left(y_{t}-y_{t}^{*}\right)+u_{t} .
$$

Taylor contracts imply a mixed backwardlooking/forward-looking price level and a strictly forward-looking inflation rate. The absence of an indexation term from equation (3) reflects Taylor's view that the dynamics of this equation should be relied on to deliver inflation persistence (see Hall and Taylor, 1997, p. 441) and that this is preferable to appealing to intrinsic inflation persistence as in Christiano, Eichenbaum, and Evans (2005) or Fuhrer and Moore (1995). The equation also reflects Taylor's belief, in contrast to Friedman's, that the expected-inflation term in the Phillips curve is formed using period- $t$ information (see Taylor, 1986a, p. 158).

\section{Wage Versus Price Stickiness}

Despite the explicitness of Taylor's specification and its nominal-contracts motivation, there is an important ambiguity common to the discussion of nominal rigidity in both Taylor's and Friedman's work. They both tended to refer to both price and wage stickiness and to play down

\footnotetext{
${ }^{21}$ These approximations involve suppressing some endogenous expectational errors that appear in the linearized Phillips curve. Because these endogenous terms are responsible for some of the effects of monetary policy in Taylor-contracts models, some authors have argued that the approximations are not innocuous-see, e.g., Westaway (1997) and Musy (2006) —and that the New Keynesian Phillips curve should not be used to represent Taylor staggered contracts.
} 
the distinction between the two. Occasionally, they would highlight wages as being subject to contracts to a greater degree than prices (see Friedman, 1966b; Taylor, 1982). But I will argue that the staggered-contracts specification that best describes their views about policy and economic structure refers to the gradual adjustment of prices, not wages.

Taylor (1986a, p. 153) was an economist who early on accepted the label of "New Keynesian"22; in the 1980s, New Keynesian economics was sometimes characterized as entailing a shift from sticky-wage models to sticky-price models (see, e.g., Mankiw, 1987). There have been occasions where Taylor has himself given the appearance of moving from a framework based on sticky wages to one based on sticky prices. For example, Taylor (1981b, p. 72) gave a price-contract interpretation of his work, explicitly replacing, in that application, an interpretation of the Phillips curve based on nominal wage contracts. Similarly, Taylor (1992, p. 22) said, "The structural interpretation I have favored involves a macroeconomic model with sticky prices and rational expectations..." More recently, Taylor (2000a, p. 1401) again explicitly reinterpreted his model as "referring directly to prices," taking firms as having staggered price contracts, and abstracting from labor market frictions. And Hall and Taylor (1997, p. 432) cited sticky prices as important, noting that "firms...find it convenient to stay with existing prices."

But evidently these exercises did not signify a fundamental change in Taylor's position, for he has never disowned the importance of wage stickiness. His belief in the importance of wage stickiness resurfaced in his recent remark, "If I had to give a list of criticisms of the recent work, it would start with the frequent abstraction from wage rigidities" (Taylor, 2007, p. 198).

Nevertheless, the move between sticky-wage and sticky-price assumptions in Taylor's work, as well as his remark in Taylor (1981b, p. 72) that

${ }^{22}$ Taylor (1981a, p. 146) noted, however, that his modeling choices and his emphasis on rules "a few years ago...[would] seem monetarist from the start," an observation which sheds light on the connections between New Keynesian economics and monetarism. his setup was "general enough" to be interpreted as referring to either wages or prices, does suggest something else to me.

What these elements suggest is that Friedman and Taylor believed that wage stickiness was largely manifested in-or was a motivation forprice stickiness. Accordingly, in both Friedman's and Taylor's work, there was a single Phillips curve in which price inflation and the output gap were the only endogenous variables. Taylor (1980, pp. 5-6), for example, moved from wages to prices by way of a constant markup and worked with a price-inflation Phillips curve. As users of dynamic general equilibrium models have shown, this Phillips curve can be rigorously derived from sticky-price models, not sticky-wage/flexibleprice models (see, e.g., Chari, Kehoe, and McGrattan, 2000, and Erceg, Henderson, and Levin, 2000).

Another reason why a sticky-price rather than sticky-wage assumption is closer to Taylor's framework is that, from the beginning, Taylor made goods-price inflation the variable that policymakers care about. Both Friedman and Taylor, as we have seen, treated the social welfare function as containing only price inflation variability and output gap variability arguments. But nominal wage inflation variability becomes a third argument of the welfare function if wages are sticky (see Erceg, Henderson, and Levin, 2000). ${ }^{23}$ In fact, I do not think that either Friedman or Taylor failed to recognize that wage stickiness in principle made wage stabilization a desirable objective. In discussing the views of Henry Simons, Friedman observed Simons's belief

that the sticky and inflexible prices were factor prices, especially wages...[Aggregate] stability in these prices...would minimize the necessity for changes in the sticky prices. (Friedman 1967, footnote 11)

This passage is notable for showing Friedman's recognition of the idea that the location of nominal stickiness bears on what is the

\footnotetext{
${ }^{23}$ It may be, as Schmitt-Grohé and Uribe (2006) argue, that rules that respond only to price inflation still perform well when wage inflation variability matters for welfare; but the issue that concerns me here is instead how to rationalize Taylor's exclusion of wage inflation fluctuations from the policymaker objective function.
} 
appropriate price index to target; if wages are sticky, the wage index should be stabilized. The fact that he and Taylor nevertheless focused on price inflation as a final objective could be taken as implying that goods-price stickiness is the economy's main nominal distortion.

It is true that Hall and Taylor (1997, pp. 43343) stress the empirical relevance of wage staggering. But they also place emphasis on the notion that wages in period $t$ are set before the realization of the period- $t$ price level. Predetermined wages, and in particular the idea that wage contracts are conditional on lagged expectations of the price level, are also an important element of Friedman's $(1968,1976)$ analysis. So I would suggest that, although prices are sticky in both Friedman's and Taylor's frameworks, the only essential assumption about the labor market is that wages are predetermined, not that they are staggered. Wage behavior therefore might be adequately represented by one-period Fischer (1977) contracts rather than by a dynamic Phillips curve.

It is true that wage stickiness provides a rationale for a disturbance term such as $u_{t}$ in equation (2) or (3) (see Erceg, Henderson, and Levin, 2000). It has therefore been argued that wage stickiness delivers a trade-off between inflation variability and output-gap variability that is absent from the sticky-price baseline. But other rationalizations are available for the $u_{t}$ term that do not rely on wage stickiness. Let us therefore consider the issue of the source of policy tradeoffs in Friedman's and Taylor's analyses.

\section{SOURCE OF TRADE-OFFS}

Taylor (1986d, p. 673) made this observation:

[A]s I showed in a 1979 Econometrica paper [Taylor, 1979], the shocks to the price adjustment equation are what cause the tradeoff between output and inflation variance: attempts to stabilize inflation sometimes require increased fluctuations in output, a factor...that I think is a major factor in the business cycle.

The Phillips curve or price adjustment equation in Taylor's framework therefore contained a shock term, for which Taylor (1981b, p. 79) offered the terminology "cost-push or supply shocks" or "contract shocks." Of these labels, "supply shocks" is less attractive because it has connotations of shocks to potential output; the shocks in question, however, are not potential GDP shocks but instead shocks to inflation that occur for a given path of the output gap (i.e., given the path of output relative to its flexible-price value).

As Taylor observes in the preceding quotation, the cost-push shock rationalizes an output-gap variance/inflation variance trade-off. It is this trade-off that Taylor has emphasized as the durable trade-off implied by Phillips curves that incorporate the natural rate hypothesis and so imply no long-run output gap/inflation level relationship. The cost-push shock therefore also underpins the "Taylor curve," depicting the menu of output-gap variance/inflation variance combinations arising under optimal monetary policy for various weights in the policymaker objective function (see Taylor, 1979). But, as discussed below, the existence of cost-push shocks is also implicit in Friedman's framework, though considerable digging is required to ascertain his views on the issue. Moreover, the treatment of cost-push shocks is symmetric across Taylor and Friedman's writings. In both their frameworks, cost-push shocks are white noise and only monetary accommodation of these shocks can propagate them (as sources of inflation movement) beyond their initial impact effect. It is Taylor's contention that monetary authorities, historically, have accommodated these shocks in the course of trading off output-gap and inflation stabilization.

Friedman (1980) acknowledged the existence of cost-push shocks: There is a "basic inflation rate" from which actual inflation can deviate as a result of "transitory shocks." That such shocks included cost-push shocks, and not just transitory shocks to the components of the output gap, is implied by Friedman and Friedman's (1984, p. 84) observation that "a sudden upward jump in the price of a product that is widely used... may temporarily raise the level of inflation."

Cost-push shocks therefore exist in Friedman's framework, but are white noise. The transitory 
character of the shocks is why he classified them as "sources of temporary blips of inflation" (Friedman, 1977b)—or, equivalently, as sources of once-and-for-all movements in the price level. In an exposition of his monetary explanation for inflation, Friedman noted that " $[\mathrm{m}]$ any phenomena can produce temporary fluctuations in the rate of inflation" for given money growth (Friedman, 1987, p. 17), thereby allowing for cost-push shocks; but he emphasized that only monetary accommodation can make them relevant for ongoing inflation. The existence of cost-push shocks is also implied by Friedman's (1987, p. 18) recognition of "often conflicting objectives of policymakers"; an expectational Phillips curve does not in itself usually imply conflicting objectives, but does so in the presence of cost-push shocks. Similarly, Friedman (2006) acknowledged the existence in principle of an inflation variance/output-gap variance trade-off of the type that Taylor uses in his work.

Taylor (1993a, p. 196) himself observed that quarterly inflation movements can reflect "blips in the price level due to factors such as temporary changes in commodity prices."

He had earlier judged these blips as reflecting "changes in relative supplies and demands for commodities [which] can cause a price index to move erratically" (Taylor, 1982). These fluctuations rationalize a cost-push shock because not all the sources of the erratic price movements can be summarized by an index of the output gap; for example, increases in a national sales tax "create a price shock" (Hall and Taylor, 1997, p. 497). The characterization of these shocks as erratic blips reflects Taylor's view of them as volatile but not persistent. Accordingly, Taylor (1981b, p. 79) suggested that the cost-push shocks have an "impulse effect" on inflation but that "monetary policy is crucial for the propagation effect." Taylor is therefore in agreement with Friedman that cost-push shocks are a white noise process with no automatic tendency to produce persistent movements in inflation. In line with this position, Hall and Taylor (1997, pp. 231, 441) use the label "price shocks"-rather than inflation shocks-for cost-push shocks; they emphasize that it is the extent to which monetary policy is predicted to accommodate these shocks that determines whether "inflation may be expected in the future" in the wake of a price shock. ${ }^{24}$

The plausibility of the white-noise characterization of the shock depends, of course, on the shock's precise rationalization. In the preceding discussion, I took the potential output concept underlying the output gap definition as inclusive of inefficient variations in potential GDP, as in Friedman (1968) and Taylor (1987). Leaving them out of the output-gap definition would put them into the Phillips curve disturbance. (See Giannoni and Woodford, 2005.) Also, if the shock is to contracts (as in Taylor, 1981b) rather than to the aggregate price level equation, this tends to imply a moving-average Phillips curve shock due to staggering of contracts. In line with this alternative, the Phillips curve shock is treated as MA(1) in some of Taylor's work. But on the whole there is a strong presumption in Friedman's and Taylor's work that the Phillips curve shock will be close to white noise.

\section{SOURCES OF SHOCKS}

Other than the white-noise Phillips curve shock, what other types of shocks did Taylor and Friedman emphasize?

Taylor has relayed a complex but consistent picture of the U.S. business cycle, which can be summarized as follows: (i) Monetary policy shocks-in the sense of exogenous, univariate shocks to the monetary policy rule-have not been an important source of U.S. business cycle fluctuations in the postwar period. (ii) Although real shocks, in addition to the Phillips curve shock discussed above, have been an important contributor to fluctuations, pre-1984 business cycle fluctuations did not reflect variations in potential output in response to real shocks. Instead,

\footnotetext{
${ }^{24}$ A white-noise interpretation of Phillips curve shocks is also consistent with Bernanke et al.'s (1999, p. 59) observation that "prior price-level rises" do not rule out the possibility that "inflation expectations remain contained." In a New Keynesian Phillips curve environment, the insensitivity of inflation expectations $\left(E_{t} \pi_{t+1}\right)$ to price-level shocks that affect $\pi_{t}$ is implied by the fact that those shocks are white noise (assuming no accommodation, and therefore unchanged expectations of the output gap).
} 
they reflected inefficient monetary policy interacting with price stickiness. (iii) Potential output does not typically vary much in response to real shocks; so, if prices were flexible and/or monetary policy were efficient, real shocks would not lead to large output fluctuations. (iv) Smooth output in the era of the Great Moderation reflects efficient monetary policy, not a reduction in the variance of real shocks.

A denial of an important role for monetary policy shocks and a stress instead on the systematic component of the monetary policy rule as an important source of fluctuations were laid out by Taylor (1982):

[I]n the last 15 to 20 years in the United States...instability has originated in supply shocks, such as the OPEC price increases. Monetary policy has influenced how these supply shocks have affected the economy...

He went on to argue that price stickiness magnified output fluctuations in the United States over the period 1952-83 (Taylor, 1986c), implying that output is more variable than potential output. Indeed, Taylor has frequently modeled potential output using a smooth trend, which suggests that he does not believe that real shocks would produce much output variability under price flexibility (see, for example, Taylor, 1986c and 1994). ${ }^{25}$ Rather, monetary policy reaction to the shocks in the postwar decades produced cycles in output and opened up the output gap, in turn leading to movements in inflation and to a later policy reaction. Taylor (1987, p. 355) went so far as to say this:

It is not much of an exaggeration to say that all the significant fluctuations in the macroeconomy during the last thirty years have been due to these relationships between output and inflation.

Although this may seem an extreme statement, it is much the same conclusion as that stated by Bernanke et al. (1999, p. 298). It also underlines

\footnotetext{
${ }^{25}$ Likewise, Hall and Taylor (1997, p. 408) define "business cycle fluctuations" as "the percentage deviation of real GDP from potential GDP."
}

the fact that attributing output instability to real shocks, as Taylor does, is not the same thing as endorsing a real business cycle account of cyclical fluctuations; on the contrary, Taylor's is a monetary view of the business cycle based on the scope for monetary policy (interacting with price stickiness) to magnify the effects of real shocks on output.

\section{Monetary Policy Rules and the Great Moderation}

Given his belief that nominal rigidities magnified U.S. output fluctuations in 1952-83 and in the existence of a cost-push shock in the Phillips curve, and assuming constant parameters in all relevant structural equations, ${ }^{26}$ the source of the Great Moderation after 1983 is limited in Taylor's framework to the following:

- reduction in the variance of monetary policy shocks,

- reduction in the variance of Phillips curve shocks,

- reduction in the variance of preference and production shocks, and

- more efficient monetary policy, reducing the upward effect of nominal rigidity on the variance of output.

The first three candidate explanations above are not ones that Taylor favors. As noted above, Taylor (1982) ruled out monetary policy shocks as important in postwar data up to 1982, so any reduction in their variance cannot be important in explaining post-1982 economic stability. An explanation based on a reduction in Phillips curve shock variance is ruled out by his confidence in a reasonably stable inflation variance/output-gap variance trade-off (see Taylor, 1994, and 1999a,

\footnotetext{
${ }^{26}$ Taylor (2005, p. 274) expresses doubt about the importance of structural change for understanding changes in U.S. business cycle behavior. Of course, the natural rate of unemployment has likely fallen in many countries, but this does not necessarily imply a structural change in aggregate output behavior. The relationship between production and employment (i.e., the Okun's law relationship) might change at the same time that the natural unemployment rate changes, in a way that cancels out implications for potential output.
} 
p. 60). Taylor (2000b) casts doubt on the likelihood that the variances of real shocks have subsided, concluding that "on balance it seems hard to make the case that exogenous shocks have gotten smaller, less frequent, or more benign."27

Logically, therefore, we come to Taylor's explanation for the Great Moderation: monetary policy. Hall and Taylor (1997, p. 429) referred to "the stability of monetary policy in the United States and other major economies from 1982 to the present." Appealing to such stability, Taylor (1999a, p. 60) argues that changes since 1982 in observed inflation variance/output-gap variance combinations reflect a movement toward the efficient policy frontier. In particular, with stable inflation there are fewer recessions triggered by attempts to rein inflation in, so the "improvement in output stability...is an important consequence of the improvement in price stability." In terms of the Phillips curve equation (3), the variability of the expected-inflation term has been reduced by the change in monetary policy rule; the inflation/output gap cycle that Taylor (1987) argued was responsible for essentially all important GDP variation has been removed.

In Taylor's framework, this change in policy did not constitute a switch from "discretion" to "rules," but instead an improvement in the specification of the U.S. monetary policy rule. Taylor (e.g., 1979, 1999c) found it useful to characterize U.S. monetary policy in the postwar decades ${ }^{28}$ as following a "rule," even though that period was frequently associated with poor economic outcomes. By taking the form of a rule (a reaction function) rather than a series of one-time decisions, monetary policy responses in this regime were often quite predictable; nevertheless, this predictability did not contribute to reduced macroeconomic uncertainty. Both Taylor and Friedman shared the belief that the virtue of rules

\footnotetext{
${ }^{27}$ See also Taylor (1998, p. 5). Because, in Taylor's view, potential output varies little, lower real shock variance would not necessarily remove a major source of fundamental output variation. Rather lower real shock variance would imply a lower variance for the inputs of the monetary policy reaction function and so would reduce the destabilizing effects of an inefficient monetary policy.

${ }^{28}$ Specifically, 1953:Q1-1975:Q4 in Taylor (1979); 1960:Q1-1979:Q4 in Taylor (1999c).
}

is that they can and should reduce uncertainty. This shared perspective is brought out by considering a statement by Friedman (1983, p. 3)

[P]olicy implications that monetarists like myself have drawn...is that the primary task of the monetary authorities should be to avoid introducing uncertainty in the economy.

(Friedman, 1983, p. 3)

alongside one by Taylor (1993b, p. 6)

Economic theory shows that things work better if there is more certainty about the conduct of monetary policy. (Taylor, 1993b, p. 6)

But the monetary policy rule in the initial postwar decades did not make "things work better," because it implied responses to the state of the economy that worsened inflation and output fluctuations.

\section{Friedman's View of Fluctuations}

Friedman advanced positions that were in essential agreement with Taylor's. Specifically, while real shocks have been a major source of economic fluctuations, this reflected monetary policy reaction to those shocks, whose effect has "merely [been] to make the economy less rather than more stable" 29 (Friedman, 1959, p. 144) and to "produce inappropriate fluctuations in output" (Friedman, 2006). Many real shocks are relevant for potential output but, were it not for monetary policy's role in magnifying their effect on actual output, the shocks would merely constitute "the myriad of factors making for minor fluctuations in economic activity" (Friedman, 1959, p. 144). Accordingly, Friedman regarded potential output as smooth: With the exception of events like the major OPEC actions, "[t]he real factors that determine the potential output of an economy...generally change slowly and gradually" (Friedman and Schwartz, 1982, p. 414). Friedman, like Taylor, accordingly attributed the Great Moderation to a more efficient monetary policy, which eliminated the destabilizing properties that monetary policy

\footnotetext{
${ }^{29}$ Woodford (1998) similarly interprets Friedman as implying that monetary policy actions in postwar decades destabilized the economy's adaptation to real shocks.
} 
has exhibited historically (see Friedman's observations in Taylor, 2001).

Friedman and Taylor therefore shared similar views on the sources of shocks. In line with the subsequent New Keynesian dynamic general equilibrium literature, they emphasized the importance of systematic monetary policy in determining output behavior. In contrast to most New Keynesian discussions, however, Friedman and Taylor treated potential output as smooth. Real shocks presumably can generate large variations in the natural rate of interest in their frameworks, but, typically, not in potential output.

\section{THE POWER AND DUTY OF MONETARY POLICY}

One way of thinking about John Taylor's work on nominal contracts is that it formalized the natural rate hypothesis, and in particular treated expectations formation and adjustment rigorously, while still preserving the emphasis on nominal rigidity (wage or price stickiness) that had been common to both Friedman's and A.W. Phillips's work. Earlier formalizations of the natural rate hypothesis, such as Lucas (1972), had not featured nominal rigidity. Here I discuss another sense in which Taylor followed Friedman's Phillips-curve ideas and in so doing further departed from the original Phillips (1958) analysis.

To incorporate Friedman's Phillips-curve views, one needs three elements: Expectations have to appear in the Phillips curve; their coefficient should be unity; and they must be endogenous. If you add expectations as an exogenous forcing process in the Phillips curve, you are introducing a variable that shifts the relation between the output gap and inflation, but you are not capturing the notion that monetary policy ultimately pins down inflation and inflation expectations alike.

And it seems to me that some of Phillips's work on inflation might be vulnerable to this criticism. Certainly Friedman thought so: $\mathrm{He}$ suggested (1976, p. 219) that the absence of expectations adjustment from the original Phillips curve analysis followed from the Keynesian tra- dition that the "price level could be regarded as an institutional datum." The fundamental contribution of Phillips curve analysis relative to pre-Phillips curve Keynesianism was to make inflation an endogenous variable. But this contribution was not integrated completely into Phillips's own analysis, as he was willing to treat a large fraction of inflation variation as exogenous (an institutional datum, in Friedman's terminology). For example, Phillips (1958) related wage inflation to unemployment and made exogenous movements in inflation a curve-shifting variableso, for example, he attributed deviations from the empirical Phillips curve to import price inflation and invoked this factor as an exogenous source of wage-price spirals. ${ }^{30}$ This perspective is clearly different from that in Friedman's writings, where monetary restraint is (by means of control of aggregate demand) a necessary and sufficient condition for inflation control. In Friedman's framework, as discussed above, there is an exogenous element to current inflationthe $u_{t}$ term in equation (2)-but it is a transitory element that hardly matters for expected inflation; in fact, it does not matter for expectations at all if the lagged-coefficient term $\gamma$ in equation (2) is zero rather than merely low.

The Friedman framework rejects the notion that shocks to specific prices can in themselves be a source of ongoing inflation. If these shocks are associated with a change in the mean of inflation, it is because the monetary authority's reaction to the shock has had the effect of shifting the mean of inflation. This position on the power of monetary policy is also that adhered to by Taylor, ${ }^{31}$ as discussed above, and shows up clearly also in policy discussions such as that of Mishkin (2007).

In Friedman's framework, therefore, inflation and expected inflation are endogenous variables ultimately pinned down by monetary policy; and the convergence of inflation and expected

\footnotetext{
${ }^{30}$ See especially Phillips (1958, p. 284).

${ }^{31}$ This is not to deny influences of Phillips's work on Taylor, which are stressed by Asso, Kahn, and Leeson (2007). But I argue that these influences were mainly reflected in Taylor's early interest in optimal control analysis rather than in Taylor's ultimate views on what monetary policy could and should do.
} 
inflation means that the output gap is zero on average irrespective of monetary policy. Phillips, on the other hand, attributed considerable inflation variation to exogenous factors, while also advancing an aggregate supply specification that implied that the output gap was generally nonzero in the long run.

\section{CONCLUSIONS}

The preceding discussion has emphasized that, although the names of Taylor and Friedman are associated with different monetary policy rules, the difference between Taylor and Friedman on how the economy works is not great. Taylor and Friedman both emphasized Phillips curve specifications that impose temporary nominal price rigidity and the long-run natural-rate restriction; and there was basic agreement between them on policymaker objectives, the sources of shocks, and policy trade-offs. Where they differed was on the extent to which structural models should enter the monetary policy decisionmaking process. This difference helps account for the differences in their preferred monetary policy rules. Their rules do share an emphasis on nominal variables and reflect the agreement between them that it is both feasible and desirable for monetary policy to preclude deviations in inflation expectations from a constant, low rate. In this respect, Taylor and Friedman both put greater emphasis than Phillips did on the power and duty of monetary policy.

\section{REFERENCES}

Asso, Francesco; Kahn, George and Leeson, Robert.

"Monetary Policy Rules: From Adam Smith to John Taylor." Presented at Federal Reserve Bank of Dallas conference John Taylor's Contributions to Monetary Theory and Policy, October 12-13, 2007.

Bernanke, Ben. S.; Laubach, Thomas; Mishkin, Frederic S. and Posen, Adam S. Inflation Targeting: Lessons from the International Experience. Princeton, NJ: Princeton University Press, 1999.
Calvo, Guillermo A. "Staggered Prices in a UtilityMaximizing Framework." Journal of Monetary Economics, September 1983, 12(3), pp. 383-98.

Chari, V.V.; Kehoe, Patrick J. and McGrattan, Ellen R. "Sticky Price Models of the Business Cycle: Can the Contract Multiplier Solve the Persistence Problem?" Econometrica, September 200, 68(5), pp. 1151-79.

Christiano, Lawrence J.; Eichenbaum, Martin and Evans, Charles. "Nominal Rigidities and the Dynamic Effects of a Shock to Monetary Policy." Journal of Political Economy, February 2005, 113(1), pp. 1-45.

Clarida, Richard; Galí, Jordi and Gertler, Mark. “The Science of Monetary Policy: A New Keynesian Perspective.” Journal of Economic Literature, December 1999, 37(4), pp. 1661-707.

Erceg, Christopher J.; Henderson, Dale W. and Levin, Andrew T. "Optimal Monetary Policy with Staggered Wage and Price Contracts." Journal of Monetary Economics, October 2000, 46(2), pp. 281-313.

Fischer, Stanley. "Long-Term Contracts, Rational Expectations, and the Optimal Money Supply Rule." Journal of Political Economy, February 1977, 85(1), pp. 191-206.

Friedman, Milton. "Statement on Monetary Theory and Policy," in Employment, Growth and Price Levels, hearings before the Joint Economic Committee. Washington, DC: Government Printing Office, 1959, pp. 605-12. Reprinted as "Monetary Theory and Policy," in R.J. Ball and P. Doyle, eds., Inflation. London: Penguin, 1969, pp. 136-45.

Friedman, Milton. A Program for Monetary Stability. Fordham, NY: Fordham University Press, 1960.

Friedman, Milton. Inflation: Causes and Consequences. New York: Asia Publishing House, 1963. Reprinted in Milton Friedman, Dollars and Deficits: Living with America's Economic Problems. Eaglewood Cliffs, NJ: Prentice Hall, 1968, pp. 21-71.

Friedman, Milton. "Interest Rates and the Demand for Money." Journal of Law and Economics, 
October 1966a, 9, pp. 71-85. Reprinted in Milton Friedman, The Optimum Quantity of Money and Other Essays. Chicago: Aldine, 1969, pp. 141-56.

Friedman, Milton. “An Inflationary Recession.” Newsweek, October 17, 1966b, p. 92.

Friedman, Milton. "The Monetary Theory and Policy of Henry Simons." Journal of Law and Economics, October 1967, 10, pp. 1-13. Reprinted in Milton Friedman, The Optimum Quantity of Money and Other Essays. Chicago: Aldine, 1969, pp. 81-96.

Friedman, Milton. "The Role of Monetary Policy." American Economic Review, March 1968, 58(1), pp. 1-17.

Friedman, Milton. "The Optimum Quantity of Money," in The Optimum Quantity of Money and Other Essays. Chicago: Aldine, 1969, pp. 1-50.

Friedman, Milton. "The Case for a Monetary Rule." Newsweek, February 7, 1972, p. 67.

Friedman, Milton. "How Much Monetary Growth?" Morgan Guarantee Survey, February 1973a, pp. 5-10.

Friedman, Milton. Money and Economic Development: The Horowitz Lectures of 1972. New York: Praeger, $1973 b$.

Friedman, Milton. "Inflation Prospects.” Newsweek, November 4, 1974a, p. 52.

Friedman, Milton. “Monetary Correction.” IEA Occasional Paper No. 41, Institute for Economic Affairs, 1974b. Reprinted in Milton Friedman, ed., Tax Limitation, Inflation and the Role of Government. Dallas: Fisher Institute, 1978, pp. 22-51.

Friedman, Milton. Price Theory. Second Edition. Chicago: Aldine, 1976.

Friedman, Milton."Discussion of 'The Monetarist Controversy’.” Federal Reserve Bank of San Francisco Economic Review, Spring 1977a, 3(1, Suppl.), pp. 12-26.

Friedman, Milton. "Why Inflation Persists.” Newsweek, October 3, 1977b, p. 84.
Friedman, Milton. "Iran and Energy Policy." Newsweek, December 31, 1979a, p. 61.

Friedman, Milton. "Inflation and Jobs." Newsweek, November 12, 1979 b, p. 97.

Friedman, Milton. "Carter's Anti-Inflation Plan." Newsweek, March 24, 1980, p. 40.

Friedman, Milton. "Monetary Policy: Theory and Practice." Journal of Money, Credit, and Banking, August 1982a, 14(3), pp. 98-118.

Friedman, Milton (1982b). "Letter to Senator Roger W. Jepsen, Vice-Chairman, Joint Economic Committee," in Monetarism and the Federal Reserve's Conduct of Monetary Policy: Compendium of Views Prepared for the Use of the Subcommittee on Monetary and Fiscal Policy, hearings before the Joint Economic Committee. Washington, DC: Government Printing Office, 1982b, pp. 73-74.

Friedman, Milton. "Defining 'Monetarism'." Newsweek, July 12, 1982c, p. 64.

Friedman, Milton. "Monetarism in Rhetoric and in Practice." Bank of Japan Monetary and Economic Studies, October 1983, 1, pp. 1-14.

Friedman, Milton. "Has Monetarism Failed?” Manhattan Report, 1984, 4(3), pp. 3-4.

Friedman, Milton. “Quantity Theory of Money,” in J. Eatwell, M. Milgate, and P. Newman, eds., The New Palgrave: A Dictionary of Economics. Volume 4, Q to Z. London: Macmillan, 1987, pp. 3-20.

Friedman, Milton. "Tradeoffs in Monetary Policy." Unpublished manuscript, Stanford University, 2006.

Friedman, Milton and Friedman, Rose D. Free to Choose. New York: Harcourt Brace Jovanovich, 1980.

Friedman, Milton and Friedman, Rose D. The Tyranny of the Status Quo. New York: Harcourt Brace Jovanovich, 1984.

Friedman, Milton, and Schwartz, Anna J. Monetary Trends in the United States and the United Kingdom: Their Relation to Income, Prices, and Interest Rates, 
1867-1975. Chicago: University of Chicago Press, 1982.

Fuhrer, Jeffrey C. and Moore, George R. "Inflation Persistence.” Quarterly Journal of Economics, February 1995, 110(1), pp. 127-59.

Giannoni, Marc P. and Woodford, Michael. "Optimal Inflation-Targeting Rules,” in Ben S. Bernanke and Michael Woodford, eds., The Inflation-Targeting Debate. Chicago: University of Chicago Press, 2005, pp. 93-162.

Hall, Robert E. and Taylor, John B. Macroeconomics. Fifth Edition. New York: W.W. Norton, 1997.

King, Mervyn A. "Changes in U.K. Monetary Policy: Rules and Discretion in Practice.” Journal of Monetary Economics, June 1997, 39(1), pp. 81-97.

Klamer, Arjo (1983). “Interview: John Taylor,” in Arjo Klamer, ed., Conversations with Economists. Totowa, NJ: Rowman and Littlefield, 1983, pp. 170-76.

Lucas, Robert E. Jr. "Expectations and the Neutrality of Money." Journal of Economic Theory, April 1972, 4(2), pp. 103-24.

Mankiw, N. Gregory. "The New Keynesian Microfoundations: Comment.” NBER Macroeconomics Annual, 1987, 2(1), pp. 105-10.

McCallum, Bennett T. "Two Fallacies Concerning Central Bank Independence." American Economic Review, May 1995 (Papers and Proceedings), 85(2), pp. 207-11.

McCallum, Bennett T. and Nelson, Edward. "Targeting versus Instrument Rules for Monetary Policy: What Is Wrong with McCallum and Nelson?: Comment." Federal Reserve Bank of St. Louis Review, September/October 2005, 87(5), pp. 627-31.

Mishkin, Frederic. "Globalization, Macroeconomic Performance, and Monetary Policy.” Presented at the Board of Governors of the Federal Reserve System conference Domestic Prices in an Integrated World Economy, Washington, DC, September 27, 2007; www.federalreserve.gov/newsevents/speech/ mishkin20070927a.htm.
Musy, Olivier. "Inflation Persistence and the Real Costs of Disinflation in Staggered Prices and Partial Adjustment Models." Economics Letters, April 2006, 91(1), pp. 50-55.

Nelson, Edward and Schwartz, Anna J. “The Impact of Milton Friedman on Modern Monetary Economics: Setting the Record Straight on Paul Krugman's 'Who Was Milton Friedman?'” Journal of Monetary Economics, 2008 (forthcoming).

Nobel Committee. "Edmund S. Phelps's Contribution to Macroeconomics.” October 9, 2006.

Orphanides, Athanasios. "The Quest for Prosperity Without Inflation.” Journal of Monetary Economics, April 2003, 50(3), pp. 633-63.

Phillips, A.W. “The Relationship Between Unemployment and the Rate of Change of Money Wage Rates in the United Kingdom, 1861-1957.” Economica, November 1958, 25(100), pp. 283-99.

Roberts, John M. “New Keynesian Economics and the Phillips Curve." Journal of Money, Credit, and Banking, November 1995, 27(4), pp. 975-84.

Rotemberg, Julio J. "Sticky Prices in the United States." Journal of Political Economy, December 1982, 90(6), pp. 1187-211.

Rotemberg, Julio J. and Woodford, Michael. "An Optimization-Based Econometric Framework for the Evaluation of Monetary Policy." NBER Macroeconomics Annual, 1997, 12(1), pp. 297-346.

Schmitt-Grohé, Stephanie and Uribe, Martin. "Comparing Two Variants of Calvo-Type Wage Stickiness.” NBER Working Paper No. 12740, National Bureau of Economic Research, 2006.

Svensson, Lars E.O. "Inflation Forecast Targeting: Implementing and Monitoring Inflation Targets." European Economic Review, October 1997, 41(6), pp. 1111-46.

Svensson, Lars E.O. “Targeting versus Instrument Rules for Monetary Policy: What Is Wrong with McCallum and Nelson?" Federal Reserve Bank of St. Louis Review, September/October 1997, 87(5), pp. 613-25. 
Taylor, John B. "Estimation and Control of a Macroeconomic Model with Rational Expectations." Econometrica, September 1979, 47(5), pp. 1267-86.

Taylor, John B. “Aggregate Dynamics and Staggered Contracts." Journal of Political Economy, February 1980, 88(1), pp. 1-23.

Taylor, John B. "Stabilization, Accommodation, and Monetary Rules." American Economic Review, May 1981a (Papers and Proceedings), 71(2), pp. 145-49.

Taylor, John B. "On the Relation Between the Variability of Inflation and the Average Inflation Rate." Carnegie-Rochester Conference Series on Public Policy, Autumn 1981b, 15, pp. 57-86.

Taylor, John B. "Letter to the Honorable Robert W. Jepsen, August 31, 1982," in Monetarism and the Federal Reserve's Conduct of Monetary Policy: Compendium of Views Prepared for the Use of the Subcommittee on Monetary and Fiscal Policy, hearings before the Joint Economic Committee. Washington, DC: Government Printing Office, 1982, pp. 156-59.

Taylor, John B. "An Appeal for Rationality in the Policy Activism Debate,” in R.W. Hafer, ed., The Monetary Versus Fiscal Policy Debate: Lessons from Two Decades. Littlefield, N.J.: Rowman and Allenheld, 1986a, pp. 151-63.

Taylor, John B. "New Econometric Approaches to Stabilization Policy in Stochastic Models of Macroeconomic Fluctuations," in Z. Griliches and M. Intriligator, eds., Handbook of Econometrics. Volume 3. Amsterdam: Elsevier, 1986b, pp. 19982055.

Taylor, John B. "Improvements in Macroeconomic Stability: The Role of Wages and Prices," in R.J. Gordon, ed., The American Business Cycle: Continuity and Change. Chicago: University of Chicago Press, 1986c, pp. 639-59.

Taylor, John B. "Reply," in R.J. Gordon, ed., The American Business Cycle: Continuity and Change. Chicago: University of Chicago Press, 1986d, pp. 672-77.
Taylor, John B. "Externalities Associated with Nominal Price and Wage Rigidities," in W.A. Barnett and K.J. Singleton, eds., New Approaches to Monetary Economics. Cambridge, U.K.: Cambridge University Press, 1987, pp. 350-67.

Taylor, John B. "The Great Inflation, the Great Disinflation, and Policies for Future Price Stability," in A. Blundell-Wignall, ed., Inflation, Disinflation and Monetary Policy. Sydney: Ambassador Press, 1992, pp. 9-31.

Taylor, John B. "Discretion versus Policy Rules in Practice." Carnegie-Rochester Series on Public Policy, 1993a, 39, pp. 195-214.

Taylor, John B. "Price Stabilization in the 1990s: An Overview," in K. Shigehara, ed., Price Stabilization in the 1990s: Domestic and International Policy Requirements. London: Macmillan, 1993b, pp. 1-6.

Taylor, John B. "The Inflation-Output Variability Tradeoff Revisited," in J.C. Fuhrer, ed., Goals, Guidelines, and Constraints Facing Monetary Policymakers. Boston: Federal Reserve Bank of Boston, 1994, pp. 23-38.

Taylor, John B. "Monetary Policy and the Long Boom.” Federal Reserve Bank of St. Louis Review, November/December 1998, 80(6), pp. 3-11.

Taylor, John B. "Commentary: Challenges for Monetary Policy: New and Old," in New Challenges for Monetary Policy. Kansas City, MO: Federal Reserve Bank of Kansas City, 1999a, pp. 59-68.

Taylor, John B. "An Historical Analysis of Monetary Policy Rules,” in John B. Taylor, ed., Monetary Policy Rules. Chicago: University of Chicago Press, 1999b, pp. 319-41.

Taylor, John B. "Staggered Price and Wage Setting in Macroeconomics,” in John B. Taylor and Michael Woodford, eds., Handbook of Macroeconomics. Volume 1B. Amsterdam: Elsevier, 1999c, pp. 100950 .

Taylor, John B. "Low Inflation, Pass-Through, and the Pricing Power of Firms." European Economic Review, June 2000a, 44(7), pp. 1389-408. 


\section{Nelson}

Taylor, John B. "Remarks for the Panel Discussion 'Recent Changes in Trend and Cycle'." Presented at the Federal Reserve Bank of San Francisco/SIEPR conference Structural Change and Monetary Policy, March 3-4, 2000b.

Taylor, John B. "An Interview with Milton Friedman.” Macroeconomic Dynamics, February 2001, 5(1), pp. 101-31.

Taylor, John B. "The International Implications of October 1979: Toward a Long Boom on a Global Scale.” Federal Reserve Bank of St. Louis Review, March/April 2005, 87(2), pp. 269-76.

Taylor, John B. "Thirty-Five Years of Model Building for Monetary Policy Evaluation: Breakthroughs, Dark Ages, and a Renaissance.” Journal of Money, Credit, and Banking, February 2007, 39(1, Suppl.), pp. 193-201.

Westaway, Peter. "How Costly Is Inflation Reduction? An Investigation of Simple Interest-Rate Rules Under Different Models of Nominal Inertia.” Presented at a Reserve Bank of New Zealand monetary policy workshop, October 20, 1997.

Woodford, Michael. "A Frictionless View of U.S. Inflation: Comment.” NBER Macroeconomics Annual, 1998, 13(1), pp. 390-418.

Woodford, Michael. Interest and Prices: Foundations of a Theory of Monetary Policy. Princeton, NJ:

Princeton University Press, 2003. 